CUAJ honours its members and friends who have passed away. We invite colleagues of the deceased to submit brief remembrances. Please limit your notice to 200 words. Send your notice to journal@cua.org or fax it to 514-395-1664.

\section{Dr. Arthur Chesley}

Dr. Chesley, 79, died Tuesday, October 25, 2011 at the Saint John Regional Hospital. He was born in Saint John on November 3, 1931. Dr. Chesley served as a urologist at the Saint John Regional Hospital and St. Joseph's Hospital for many years. Arthur is survived by his beloved wife, Doris, of 55 years, his daughters Heather (Peter) Fisher, Julia (Christopher) Hardt and his son Brian. Dr. Chesley obtained his M.D.C.M. from Dalhousie University in 1955. His postgraduate work included an internship in surgery at the Royal Victoria Hospital and a urology and pathology internship at the Montreal General Hospital. Dr. Chesley became a Royal College Fellow (FRCSC) in urology in 1960. Prior to retirement he was Professor of Urology at Dalhousie University. Dr. Chesley was a true "man of science", dedicating the better part of his medical career to research and invention in addition to his practice. As a researcher Dr. Chesley was a pioneer in the development of a prostate cancer awareness program in Canada in 1981. In 1982 he received a grant from the N.B. Terry Fox Fund and subsequent grants were obtained to continue the development of the program. When the Fund was closed in 1989 he established Prostate Cancer Detection Inc., a charitable organization, to continue supporting prostate cancer research activities in Saint John. At this time he also became involved with the American Cancer Society as co-chairman of the National Prostate Cancer Detection Project and initiated a prostate cancer support group in Saint John.

In addition to his research, Dr. Chesley was the first to introduce numerous medical techniques and inventions to the Maritime Provinces. His inventions included a special needle guide for prostatic biopsies which allowed urologists not having access to ultrasound equipment to perform accurate prostate biopsies. In recognition of the many contributions to the community and medical profession, Dr. Chesley was presented with the Group of Five Gluskap Award (1989), the Commemorative Medal marking the 125th Anniversary of the Confederation of Canada (1992), the New Brunswick Medical Society Order of Merit (1995), and the American Cancer Society's National Prostate Cancer Detection Program Award (1996). In 1998 Dr. Chesley was awarded an honorary Doctor of Science degree from UNBSJ. Dr. Chesley was devoted to his native city and province and the Chesley Family Endowment at Dalhousie University is his legacy to Saint John.

Adapted from InMemoriam.Ca. 2011.

Cite as: Can Urol Assoc J 2011;5(6):436; http://dx.doi.org/10.5489/cuaj.11283

\section{CORRECTION}

The In Memoriam in the October 2011 issue should have read Dr. Everett Cox Reid. ${ }^{1}$ We sincerely apologize to Dr. Reid's family and friends for inversing the middle and last names. We thank CUAJ readers for their notes of sympathy. He will be remembered as a compassionate physician and mentor.

Cite as: Can Urol Assoc J 2011;5(6):436; http://dx.doi.org/10.5489/cuaj.11284

\section{Reference}

1. In Memoriam. Can Urol Assoc J 2011;5:364. http://dx.doi.org/10.5489/cuaj.11204 